\title{
Integrated management of charcoal rot disease of soybean caused by Macrophomina phaseolina
}

\author{
M. Tahmidur Rahman, Md. Tanbir Rubayet*(D) , Abu Ashraf Khan and M. Khurshed Alam Bhuiyan
}

\section{Address:}

Department of Plant Pathology, Faculty of Agriculture, Bangabandhu Sheikh Mujibur Rahman Agricultural University, Gazipur-1706, Bangladesh

*Corresponding author: Md. Tanbir Rubayet, Email: tanbir86plp@gmail.com

Received: 29-7-2020; Accepted: 17-12-2020; Published: 2-1-2021

$\underline{10.21608 / \text { ejar.2021.37644.1019 }}$

\section{ABSTRACT}

An attempt was taken for the management of charcoal rot disease of soybean caused by Macrophomina phaseolina using the integration of bio-agent with fungicide and organic amendment. Before going to the field experiments, different in-vitro trials were conducted to select a virulent isolate of $M$. phaseolina, an effective antagonistic isolate of Trichoderma harzianum, suitable fungicide and organic amendment. Among the seven isolates of M. phaseolina, MSP-4 isolate was selected as the test pathogen by the pathogenicity test. On the contrary, among the eighty-seven isolates of $T$. harzianum, ISR-26 isolate showed the highest $(81.85 \%)$ inhibition of radial growth of test pathogen. In the case of fungicidal evaluation trial, Provax 200WP was found the most effective seed treating fungicide at the moderate concentration (150 ppm), while experienced the highest concentration of Conza 5\%EC and Bavistin 50WP for inhibiting the radial growth of M. phaseolina isolate MSP-4. Additionally, in-vitro trial of different organic amendments, mustard oil cake was found the most active organic amendment for reducing the growth (50.92\%) and development of test pathogen at $3 \%$ concentration level. In the field trial, integrated use of $T$. harzianum with Provax 200WP, and mustard oil cake under the treatment with $\mathrm{T}_{9}$ appeared the best treatment in reducing seedling mortality (80.47\%), disease incidence $\left(80.14 \%\right.$ ) as well as disease severity $(88.55 \%)$ caused by the test pathogen. Moreover, treatment $\mathrm{T}_{9}$ was the best treatment not only for the management of the soybean disease but also increased the significant quantity of yield (104.42\%). This integrated approach could be more helpful for soybean growers all over the world.

Keywords: M. phaseolina, T. harzianum, Fungicides, Organic amendments, and Soybean

\section{INTRODUCTION}

Soybean (Glycine max L.) belongs to the family Leguminosae which contributes around twenty-five percent of the global edible oil as well as about two-thirds of the world's protein concentrate for livestock feeding. Additionally, soybean meal is a valuable constituent in formulated feeds for poultry and fish. In 2017-18, the total soybean cultivable land was 59.49 thousand hectares and yield production was 99 thousand tons with an average yield of $1.66 \mathrm{t} / \mathrm{ha}$ (Anon, 2018). Nowadays, soybean is becoming a popular winter crop in Bangladesh. Growers are becoming interested to cultivate soybean instead of other legume crops. But there are some challenges for the production of soybean such as quality seeds, climatic conditions, differences in rainfall pattern, an outbreak of diseases and pests, etc. Among these features, plant diseases are one of the most important factors for the cultivation of soybean. More than hundreds of plant pathogens are identified to affect soybean where sixty-six fungi, six bacteria, eight viruses and seven nematodes (Sinclair, 1988).

Macrophomina phaseolina is one of the most destructive pathogens which can be spread by contaminated seeds and soil (Yesil and Bastas, 2016). This notorious soil-borne fungus causes charcoal rot disease of soybean. The symptoms of charcoal rot disease generally occur during the seedlings to flowering stage. The major characteristic is to develop brown lesions on the hypocotyl of emerging seedlings. Amid growing season, leaflets on infected plants may be small, wither and turn a brown color. The taproot of the plant and ground line stem may become streaked with a light grey color. A plethora of small black specks may form underneath of epidermis and inside the lower stem and taproot which appears charcoal-sprinkled. Finally, the reddish-brown discoloration can also develop in the pith and vascular tissues of the root and the plant become wilted and die.

However, management of this pathogen is sometimes difficult because of its long persistence in seed and wide host range. Chemical fungicides are effective against this fungus but these chemicals are expensive and harmful for humans and animals. Not only detrimental for living organisms but also contaminated the environment rigorously. Moreover, indiscriminate use of chemical pesticides and fertilizers in modern agriculture has resulted in the development of several problems such as pesticide resistance in pests, the resurgence of target and non-target pests, destruction of beneficial organisms like honey bees, and chemical residues in food, feed and fodder (Arefin et al., 2019). On the other hand, Integrated Disease Management (IDM) strategy is comparatively safe, environment friendly and durable. Integration of chemical, cultural and biological approaches to control M. phaseolina may be most effective rather than discretely application (Abd-Elsalam, 2010). Effective and proficient use of chemicals, bio-control agents and organic amendments, therefore, may be potential to control the charcoal rot disease of soybean caused by M. phaseolina. Several reporters (Rubayet and Bhuiyan, 2016; Liton et al., 2019; Ahmed et al., 2019) found that combined application of fungicide, organic amendment (mustard oilcake), biocontrol (Trichoderma sp.) is highly effective for controlling the soil-borne as well as seed-borne plant pathogens during crops cultivation (Aly et al., 2007). This combined package not only minimizes plant diseases but also improves soil health and ultimately crop production. However, a few studies have been done on the management of charcoal rot disease of soybean but there is no report on integrated management of the above-mentioned disease of soybean in Bangladesh.

Considering the aforesaid facts, the present research was undertaken to evaluate the effectiveness of integrated disease management strategies consisted of bio-agent, fungicide and organic amendment against charcoal rot disease of soybean caused by $M$. phaseolina. 


\section{MATERIALS AND METHODS:}

\section{Isolation and preservation of $M$. phaseolina isolates:}

Seven isolates of M. phaseolina designated as MSP-1 to MSP-7were isolated from infected root, and pod tissues of soybean, bush bean, and pea. The specimens which had typical symptoms of root rot were selected from the infected fields. The fungal isolates were isolated according to the standard method (Mian, 1995). Then, the fungal colonies were grown on PDA and identified according to Barnett and Hunter (1972). The isolates were purified following the hyphal tip technique and stored in PDA slants at $10^{\circ} \mathrm{C}$.

\section{Cultural characterization of $M$. phaseolina isolates:}

The selected isolates MSP-1 to MSP-7 were individually inoculated into three replicated PDA plates and incubated according to the Rahman et al. (2020b). After 7 days of incubation, observation on cultural characteristics such as colony color, colony type, pycnidia population, and pycnidia distribution was recorded. The isolates colony type and colony color were fluffy and dark grey. The pycnidia and pycnidiospores were observed under a compound microscope.

\section{Inoculum preparation of the tested pathogen:}

Inoculum of the test pathogen isolates was made and kept following the standard method (Rubayet and Bhuiyan, 2016).

\section{Pathogenicity test:}

The pathogenicity test was done of seven selected isolates of $M$. phaseolina designated as MPS- 1 to MPS-7 against soybean seedlings in the pot culture experiment according to the standard methods (Rubayet et al., 2017; Liton et al., 2019).

Collection, isolation and preservation of $T$. harzianum isolates:

A total of 87 isolates of $T$. harzianum whereas 37 isolates were isolated from the different crop fields of Gazipur, Chuadanga and Meherpur districts of Bangladesh following the soil dilution plate technique (Dhingra and Sinclair, 1985). And rest of the 50 isolates were collected directly from the plant pathology laboratory, Bangabandhu Sheikh Mujibur Rahman Agricultural University (BSMRAU), Bangladesh. All the isolated Trichoderma spp. were identified as T. harzianum based on the different morphological characteristics like hyphal growth, spore formation and color. The pure culture of T. harzianum was conserved for future application (Das et al., 2019).

\section{Screening of $T$. harzianum against $M$. phaseolina isolate MSP-4:}

The in-vitro screening was accompanied to assess the antagonistic effect of selected 87 isolates of $T$. harzianum against test pathogen on PDA medium by dual plate culture technique (Dhingra and Sinclair, 1985). After 7 days of incubation, the inhibition percentage of radial growth of the test pathogen was calculated using the following formula (Sundar et al., 1995).

$\%$ inhibition of growth $=\frac{P-Q}{P} \times 100$

Where, $\mathrm{P}=$ Mycelial growth of the pathogen in absence of $T$. harzianum (control), and Q = Mycelial growth of the pathogen in presence of $T$. harzianum.

\section{Evaluation of fungicides and organic amendments against $M$. phaseolina isolate MSP-4:}

Effect on radial colony growth:

Five fungicides (Conza 5\%EC, Cabrio*Top 60WP, Provax 200WP, Bavistin 50WP and Dithane M-45) at three different concentrations viz., 75, 150 , and 300 ppm were assessed their effect on radial colony growth following poison food technique (Dhingra and Sinclair, 1985) (Table 1). Three replicated plates with CRD were used for each dose of each fungicide. The inoculated plates were incubated in the laboratory having an ambient temperature of $28 \pm 3{ }^{\circ} \mathrm{C}$ (Rubayet et al., 2011). Data on radial colony diameter was recorded after 3-days of incubation when the check plate was enclosed with the growth of the test pathogen. The diameter of colonies on PDA with and without fungicide was measured from the bottom side of the Petri dishes. The inhibition of radial colony growth in amended plates was calculated based on colony diameter of the check plate following the formula as suggested by Sundar et al. (1995) mentioned earlier.

Another in-vitro experiment was conducted to determine the effect of organic amendments (mustard oil cake, sesame oil cake, soybean oil cake, coconut oil cake, and tea waste) at 3 different concentrations viz. 1, 2, and 3\% on the growth of M. phaseolina isolate MSP4 following standard techniques (Dhingra and Sinclair, 1985; Rubayet et al., 2011; Rubayet et al., 2018). Three days after incubation the inhibition of radial colony growth in the amended plates was computed based on colony diameter of the control plate using the same formula as stated above by Sundar et al. (1995).

Table 1. List of fungicides and their active ingredients applied in the current study

\begin{tabular}{|l|l|l|}
\hline Fungicides & Active ingredients & Modes of action \\
\hline Conza 5\%EC & Hexaconazole 5\% EC & Systemic \\
\hline Cabrio*Top & Pyroclostribin 5\% + Metirum 55\% WP & Systemic and contact \\
\hline Provax 200WP & Carboxin 37.5\% + Thiram 37.5\% WP & Systemic and contact \\
\hline Bavistin 50WP & Carbendazim 50\% WP & Systemic \\
\hline Dithane M-45 & Mancozeb 80\% WP & Systemic and contact \\
\hline
\end{tabular}

Effect on mycelial dry weight:

The effect of the mentioned fungicides on mycelial dry weight of $M$. phaseolina isolate MSP-4 was determined by Rahman et al. (2020a). In the meantime, the effect of organic amendments on mycelial dry weight of $M$. phaseolina isolate MSP-4 was determined by growing fungi in the Potato Dextrose Broth (PDB) amended with individual organic amendments at the concentration of 1,2 , and $3 \%$ ( $/ \mathrm{v}$ ) following the same technique as described earlier (Dhingra and Sinclair, 1985). Inhibition of mycelial dry weight in the amended broth was calculated based on the dry weight in control treatment following the above-mentioned formula. 
Compatibility of $T$. harzianum isolate ISR-26 with fungicides and organic amendments:

The compatibility test of $T$. harzianum isolate ISR-26 with fungicides and organic amendments were justified according to Rubayet and Bhuiyan (2012), and Rahman et al. (2020a).

\section{Preparation of inoculum:}

The selected isolate of M. phaseolina isolate MSP-4 and T. harzianum isolate ISR-26 were used for the production of wheat grain colonized inoculum distinctly following the standard procedures (Rubayet and Bhuiyan, 2016).

Integrated effect of Trichoderma, fungicide and organic amendment on $M$. phaseolina isolate MSP-4:

A field experiment was conducted to find out the effect of integrated use of $T$. harzianum isolate ISR-26, seed treating fungicide Provax-200 WP, and mustard oil cake against the charcoal rot disease of soybean caused by $M$. phaseolina isolate MSP-4 and response on yield production. The test pathogen was artificially inoculated in the respective experimental field before sowing the seeds.

\section{Cultivation of soybean:}

Cultivable land was prepared and made the plot according to Rahman et al. (2018). Nine different treatments were allotted randomly to nine-unit plots per block. Before sowing, seeds were soaked for 24 hours to facilitate the germination and also dried for avoiding excess water. For the respective treatment of trial, seeds were treated with Provax 200 WP @ $0.2 \mathrm{~g} / 100 \mathrm{~g}$ seeds. Then, seeds were sown in lines uniformly by hand $(45 \mathrm{Kg} / \mathrm{ha})$ keeping the row-to-row distance of $25 \mathrm{~cm}$. Weeding, mulching and irrigation were done in the experimental field whenever necessary.

\section{Treatments of the field experiment:}

$\mathrm{T}_{1}=$ Fresh seeds sown in sterilized ( $5 \%$ formaldehyde) soil (Control-1), $\mathrm{T}_{2}=$ Soil inoculated with pathogen (SIP) + Fresh seeds (Control-2), $\mathrm{T}_{3}=$ SIP + Fungicide Treated Seeds (FTS), $T_{4}=S I P+$ Wheat Grains Colonized $T$. harzianum isolate ISR-26 (WGCT) + Fresh seeds, $T_{5}=S I P+O$ Organic Amendment $(\mathrm{OA})+$ Fresh seeds, $\mathrm{T}_{6}=\mathrm{SIP}+\mathrm{WGCT}+\mathrm{FTS}, \mathrm{T}_{7}=\mathrm{SIP}+\mathrm{WGCT}+\mathrm{OA}+$ Fresh seeds, $\mathrm{T}_{8}=\mathrm{SIP}+\mathrm{OA}+\mathrm{FTS}$, and $\mathrm{T}_{9}=\mathrm{SIP}+\mathrm{WGCT}+\mathrm{OA}+\mathrm{FTS}$.

\section{Treatments application methods:}

Nine treatments were tested in the open field under artificially inoculated conditions. Control-1 was sterilized with $1 \%$ formaldehyde by drenching the soil properly. After treatment with formaldehyde, the soil was covered with transparent polyethylene sheets. Polyethylene sheets were removed after 48 hours and exposed to air 7 days before sowing. Inoculum of a selected isolate of $M$. phaseolina was thoroughly mixed with soil according to design and layout @ $90 \mathrm{~g} / \mathrm{m}^{2}$ soil as suggested by Yuen et al. (1994). Water-soaked sterilized and air-dried wheat grains but not colonized by the fungal isolate was inoculated at the same rate in the control plots. Mustard oil cake was mixed with the soil of concerning treatments plot was used @ $5 \mathrm{t} / \mathrm{ha}$. After 21-days, wheat grains colonized $T$. harzianum isolate ISR-26 was mixed thoroughly with the soil of selected treatments @ $50 \mathrm{~g} / \mathrm{m}^{2}$ (Abd-El-Khair et al., 2010). Then after three days, soybean seeds were sown in the plots of all treatments. In the case of seeds treatment with fungicide, around $100 \mathrm{~g}$ seeds were taken in a conical flask then added $0.2 \mathrm{~g}$ Provax 200WP and mixed properly before sowing.

\section{Data recording:}

The number of emerged seedlings was recorded after 15-days of sowing and converted into percent of pre-and post-emergence mortality in seedlings. Diseased seedlings were counted every alternate day and continued up to 30 days after sowing (Rahman et al., 2018). Germination and seedling mortality were expressed in percentage based on the total number of seeds planted. The disease incidence (DI), percent disease index (PDI) and total yield were assessed by the following formulas (Rahman et al., 2013; Razaq et al., 2015).

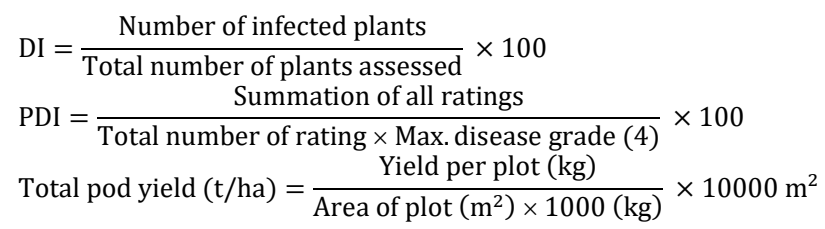

\section{Data analysis:}

Statistically, data were analyzed using the MSTAT-C computer program after proper transformation whenever it was necessary. The treatment means were compared following Duncan's Multiple Range Test (DMRT).

\section{RESULTS}

Isolation and cultural characterization of M. phaseolina isolate MSP-4:

All the isolates were identified based on the morphological characteristics of pycnidia, pyncidiospores, conidiophores, etc. which were produced on PDA medium (Wheeler, 1975). Pycnidia were 100-200 $\mu \mathrm{m}$ in diameter, dark to greyish, becoming black with age, globose or flattened globose, membranous to sub-carbonaceous with rod-shaped conidiophores and shorten ostiole. Microsclerotia were developed by hyphal cell aggregation. It was black and are variable in size (50-150 $\mu \mathrm{m}$ ) (Table 2 and Fig. 1).

Table 2. Cultural characteristics of M. phaseolina isolates on PDA medium

\begin{tabular}{|l|l|l|l|l|}
\hline Isolates & Locations & Source Crops & Colony colors & Colony types \\
\hline MPS-1 & BSMRAU & Jute & Dark Gray & Fluffy \\
\hline MPS-2 & Meherpur & Soybean & Dark Gray & Fluffy \\
\hline MPS-3 & BSMRAU & Soybean & Dark Gray & Fluffy \\
\hline MPS-4 & BSMRAU & Soybean & Dark Gray & Fluffy \\
\hline MPS-5 & BSMRAU & Papaya & Dark Gray & Fluffy \\
\hline MPS-6 & BSMRAU & Eggplant & Dark Gray & Fluffy \\
\hline MPS-7 & Chuadanga & Soybean & Dark Gray & Fluffy \\
\hline
\end{tabular}




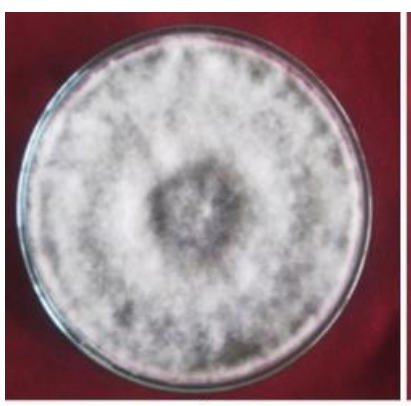

A

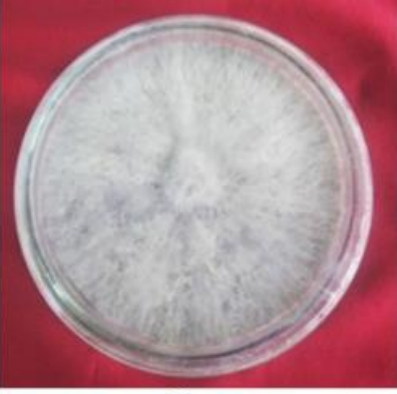

B

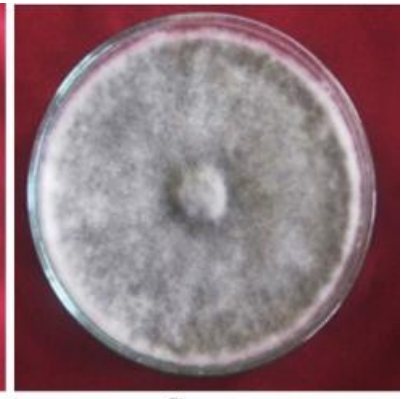

C

Fig. 1. Cultural variation of $M$. phaseolina isolates on PDA medium (A-C).

Pathogenicity test of $M$. phaseolina isolates in pot culture:

All the isolates of $M$. phaseolina showed variability in their pathogenicity causing 29.62 to $74.06 \%$ seedling mortality due to pre-and postemergence damping-off of soybean. The isolate MPS-4 showed the highest pre-emergence seedling mortality $48.14 \%$, followed by MPS-3 (40.72\%). Additionally, the highest post-emergence seedling mortality was found in isolate MPS-4 (25.92\%) followed by MPS-2 (18.52\%). Moreover, the total mortality (74.06\%) was observed in MSP-4 isolate (Table 3). Based on the present findings isolate MPS-4 was selected for further study.

Table 3. Pathogenicity test of M. phaseolina isolates in pot culture

\begin{tabular}{|c|c|c|c|}
\hline \multirow[t]{2}{*}{ Isolates } & \multicolumn{3}{|c|}{ \% seedling mortality } \\
\hline & Pre-emergence & Post-emergence & Total \\
\hline MPS-1 & 25.92 & 11.11 & $37.03^{\mathrm{c} \tilde{c}_{(37.44) B}}$ \\
\hline MPS-2 & 18.52 & 18.51 & $37.03^{c}(37.44)$ \\
\hline MPS-3 & 40.72 & 14.81 & $55.55^{b}(48.19)$ \\
\hline MPS-4 & 48.14 & 25.92 & $74.06^{a}(59.99)$ \\
\hline MPS-5 & 14.81 & 14.81 & $29.62{ }^{c}{ }_{(32.88)}$ \\
\hline MPS-6 & 29.63 & 7.40 & $37.03^{c}(37.44)$ \\
\hline MPS-7 & 37.03 & 3.70 & 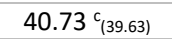 \\
\hline Control & 0.00 & 0.00 & $0.00^{d}(1.654)$ \\
\hline
\end{tabular}

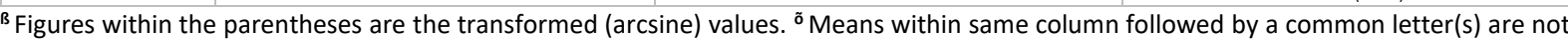
significantly different $(\alpha=0.05)$.

\section{Screening of $T$. harzianum against $M$. phaseolina Isolate MSP-4:}

An in-vitro experiment was conducted to evaluate the antagonistic efficiency of 87 isolates of $T$. harzianum against one selected isolate of M. phaseolina isolate MSP-4 following the dual plate culture technique. The highest $81.85 \%$ reduction of mycelial growth of test pathogen was found with the T. harzianum isolate ISR-26 followed by the isolate MYT-75 (80.74\%), and DT-5 (80.19\%) (Fig. 2 \& 3). On the other hand, the lowest inhibition (55.74\%) in radial growth was observed with the isolate THC-6 against the test pathogen. Moreover, all T. harzianum showed a great variation in their degree of antagonism which differs from isolate to isolate against test pathogen. The degree of antagonism as measured based on the class number on the indexing scale of 1-5 ranged from 1 to 3 against M. phaseolina isolate MSP-4. A total of 15 isolates (17.24\%) showed antagonism class at 1,31 isolates (35.63\%) class at 2, 41 isolates (47.13\%) class at 3, and no isolate was recorded under the antagonism class at 4 or 5 (Table 4).

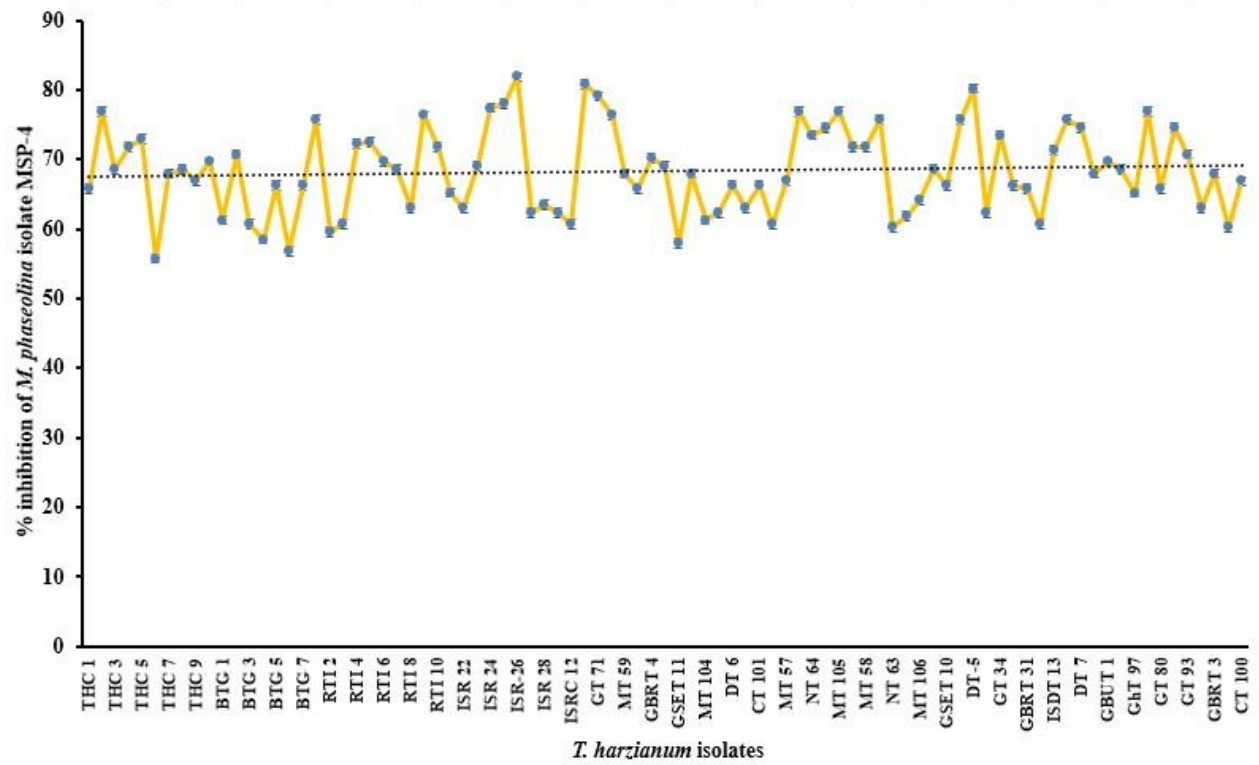

Fig. 2. Percent inhibition of $M$. phaseolina isolate MSP-4 mycelial growth by $T$. harzianum isolates in dual culture on PDA. 


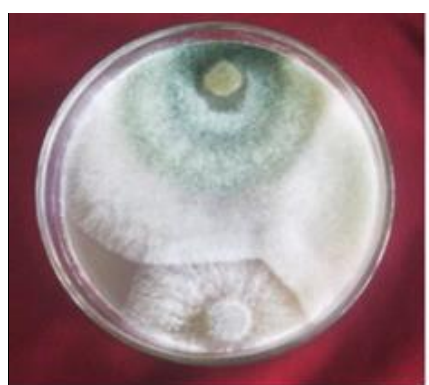

A

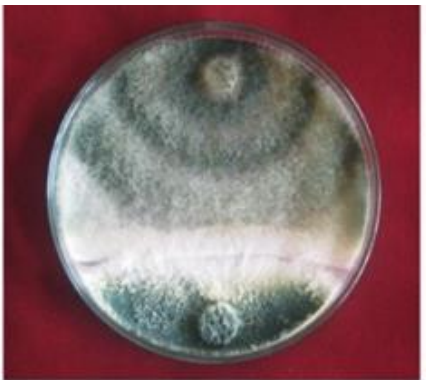

B

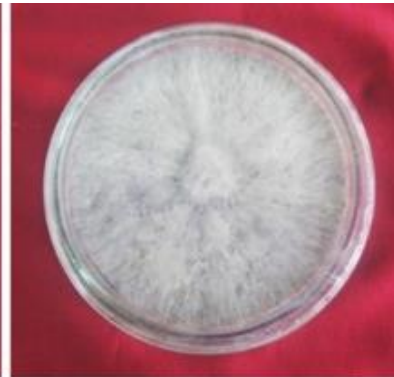

C

Fig. 3. Antagonism of $T$. harzianum against $M$. phaseolina isolate MSP-4 on PDA $(A=I S R-26, B=D T-5, C=C o n t r o l)$.

Table 4. Antagonism of T. harzianum isolates against M. phaseolina isolate MSP-4 in dual culture on PDA

\begin{tabular}{|c|c|c|c|}
\hline Classes & T. harzianum isolates & $\begin{array}{l}\text { Number of } \\
\text { isolates }\end{array}$ & $\%$ isolates \\
\hline 1 & $\begin{array}{l}\text { ISR-26, DT-5, MYT-75, GT-71, ISR-25, ISR-24, MT-105, GT-76, THC-2, GT-36, RTI-9, } \\
\text { MT-55, RTI-1, CT-99, CT-102 }\end{array}$ & 15 & 17.24 \\
\hline 2 & $\begin{array}{l}\text { RTI-4, NT-66, GT-44, DT-7, GT-34, NT-64, THC-5, RTI-5, MT-107, RTI-10, MT-58, } \\
\text { THC-4, ISDT-13, BTG-2, GT-93, GBRT-4, THC-10, GBUT-1, RTI-6, GT-35, ISR-23, GT- } \\
\text { 23, RTI-7, MT-52, THC-8, THC-3, GUT-19, THC-7, MT-59, MT-51, GBRT-3 }\end{array}$ & 31 & 35.63 \\
\hline 3 & $\begin{array}{l}\text { ISDT-15, NT-65, TT-112, RTI-8, MT-53, BTG-7, MT-104, THC-9, THC-1, GBRT-31, GT- } \\
\text { 74, CT-100, MT-57, MT-106, GT-80, DT-6, RT-90, ISR-28, GBUT-2, CT-101, GHT-98, } \\
\text { GSET-10, ISDT-16, ISR-22, GT-77, ISR-27, GHT-97, BTG-5, ISR-21, ISRC-12, NT-63, } \\
\text { BTG-3, ISRC-11, BTG-1, RTI-3, GT-20, RTI-2, BTG-4, GSET-11, BTG-6, THC-6 }\end{array}$ & 41 & 47.13 \\
\hline 4 & - & - & - \\
\hline 5 & - & - & - \\
\hline Total & & 87 & \\
\hline
\end{tabular}

Efficacy of fungicides against $M$. phaseolina isolate MSP-4:

In-vitro trial, the fungicides such as Provax 200WP and Conza 5\%EC at higher concentrations (150 ppm and 300 ppm) and Bavistin $50 \mathrm{WP}$ at $300 \mathrm{ppm}$ were completely inhibited the radial growth of $M$. phaseolina. The second-best result was obtained with Bavistin $150 \mathrm{WP}$ ppm followed by 75 ppm. Cabrio*Top showed reverse result against mycelial growth of the test pathogen even at the highest concentration. Besides, Dithane M-45 showed a moderate inhibitory effect on radial growth which was $28.88,42.59$, and $65.55 \%$ at 75 ppm, 150 ppm, and 300 ppm, respectively (Table 5 and Fig. 4).

Similarly, the result of the inhibition of mycelial dry weight was also found alike with the five fungicides. The maximum inhibition of mycelial dry weight was achieved with all concentrations of Bavistin 50WP and with 150 ppm and 300 ppm of Provax $200 W P$ and Conza $5 \%$ EC, respectively. Conza 5\%EC at 75 ppm showed $87.64 \%$ inhibition followed by Provax 200WP (82.63\%) at 75 ppm, and Dithane M-45 $(80.96 \%)$ at $300 \mathrm{ppm}$, respectively. Cabrio*Top showed very poor performance in inhibiting mycelial dry weight. The results of the present study revealed that Conza 5\%EC was the most effective fungicide against $M$. phaseolina isolate MSP-4 which was followed by Provax $200 \mathrm{WP}$, and Bavistin 50WP, respectively.

Table 5. In-vitro evaluation of fungicides against the radial growth and mycelial dry weight of test pathogen

\begin{tabular}{|c|c|c|c|}
\hline \multirow[t]{2}{*}{ Fungicides } & \multirow[t]{2}{*}{ Concentrations (ppm) } & \multicolumn{2}{|c|}{ \% Inhibition in M. phaseolina isolate MSP-4 } \\
\hline & & Radial growth & Mycelial dry weight \\
\hline \multirow[t]{3}{*}{ Conza 5\%EC } & \multirow{3}{*}{$\begin{array}{c}75 \\
150 \\
300\end{array}$} & $72.59^{d}(58.43)$ & $87.64^{b}(69.47)$ \\
\hline & & $100^{\mathrm{a}}(88.35)$ & $100^{\text {a õ }}(88.35)$ B \\
\hline & & $100^{a}(88.35)$ & $100^{\mathrm{a}}(88.35)$ \\
\hline \multirow[t]{3}{*}{ Cabrio*Top } & \multirow{3}{*}{$\begin{array}{c}75 \\
150 \\
300\end{array}$} & $0.00^{h}(1.65)$ & $0.00^{\mathrm{h}}(1.65)$ \\
\hline & & $0.00^{h_{(1.65)}}$ & $4.80^{g}(12.66)$ \\
\hline & & $0.00^{h}(1.65)$ & $7.62^{f}(15.99)$ \\
\hline \multirow[t]{3}{*}{ Provax 200WP } & \multirow{3}{*}{$\begin{array}{c}75 \\
150 \\
300\end{array}$} & $64.81 \mathrm{e}_{(53.62)}$ & $82.63^{c}(65.39)$ \\
\hline & & $100^{\mathrm{a}}(88.35)$ & $100^{a}(88.35)$ \\
\hline & & $100^{\mathrm{a}}(88.35)$ & $100^{\mathrm{a}}(88.35)$ \\
\hline \multirow[t]{3}{*}{ Bavistin 50WP } & \multirow{3}{*}{$\begin{array}{c}75 \\
150 \\
300\end{array}$} & $83.33^{c}(65.94)$ & $100^{\mathrm{a}}(88.35)$ \\
\hline & & $86.66^{b}(68.69)$ & $100^{a}(88.35)$ \\
\hline & & $100^{\mathrm{a}}(88.35)$ & $100^{\mathrm{a}}(88.35)$ \\
\hline \multirow[t]{3}{*}{ Dithane M-45 } & \multirow{3}{*}{$\begin{array}{c}75 \\
150 \\
300\end{array}$} & $28.88^{\mathrm{g}}(32.50)$ & $35.85^{\mathrm{e}_{(36.78)}}$ \\
\hline & & $42.59^{f}(40.75)$ & $55.28^{d}(48.04)$ \\
\hline & & $65.55^{\mathrm{e}}{ }_{(54.06)}$ & $80.96^{c}(64.14)$ \\
\hline Control & & $90 \mathrm{~mm}$ & $0.438 \mathrm{~g}$ \\
\hline
\end{tabular}

${ }^{B}$ Figures within the parentheses are the transformed (arcsine) values. ${ }^{\circ}$ Means within the same column followed by a common letter(s) are not significantly different $(\alpha=0.05)$. 


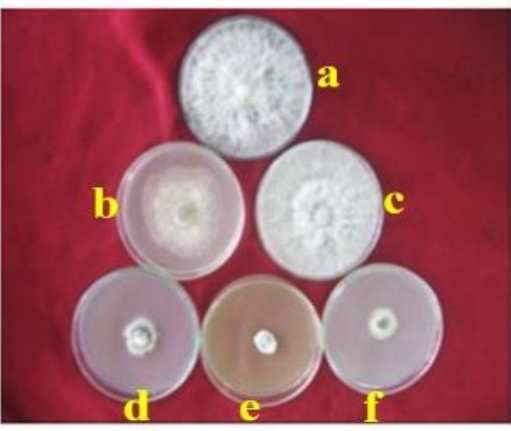

A

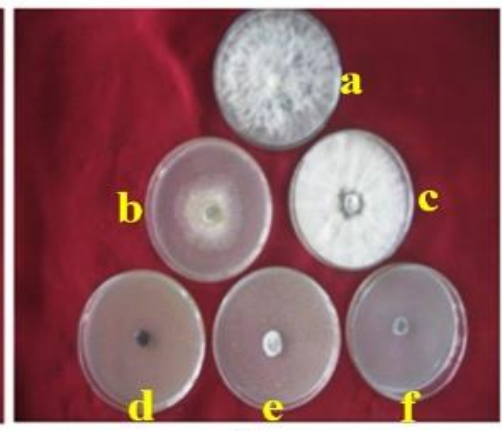

B

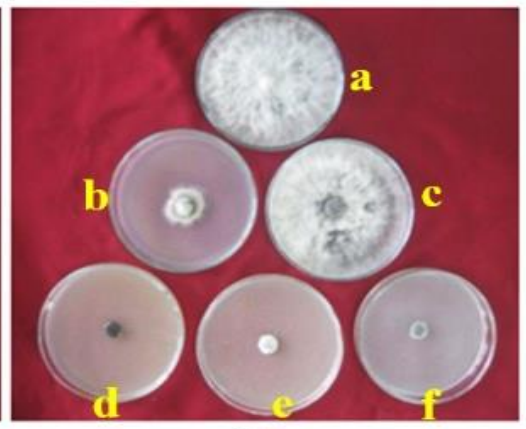

C

Fig. 4. Effect of fungicides at different concentrations on radial growth of $M$. phaseolina isolate $M S P-4(A-C, W h e r e A=75 p p m ; B=150$ ppm; C= 300 ppm; $a=$ Control; $b=$ Dithane M-45; c= Cabrio*Top; $d=$ Provax 200WP; e= Bavistin 50WP; $f=$ Conza 5\%EC).

In-vitro evaluation of organic amendments against $M$. phaseolina isolate MSP-4:

Another experiment was conducted to evaluate the effect of different organic amendments on the growth and development of $M$. phaseolina isolate MSP-4. The highest reduction (50.92\%) in radial colony diameter was achieved with mustard oil cake at $3 \%$ concentration followed by $2 \%$ soybean oil cake ( $25.18 \%)$, and $2 \%$ mustard oil cake. All other amendments were found least effective against $M$. phaseolina. Around null inhibition of radial growth was observed with all concentrations of tea waste and $1 \%$ conc. of coconut, and sesame oil cake. Besides, evaluation of mycelial dry weight the highest (55.82\%) inhibition was observed with $3 \%$ mustard oil cake followed by $3 \%$ conc. of sesame oil cake, whereas tea waste was found the lowest effect on mycelial dry weight (Table 6 and Fig. 5). This result of the present investigation revealed that mustard oilcake was the most effective in inhibiting the growth of $M$. phaseolina.

Table 6. In-vitro evaluation of organic amendments against test pathogen

\begin{tabular}{|c|c|c|c|}
\hline \multirow[t]{2}{*}{ Organic amendments } & \multirow[t]{2}{*}{ Concentration (\%) } & \multicolumn{2}{|c|}{ \% Inhibition in M. phaseolina isolate MSP-4 } \\
\hline & & Radial growth & Mycelial dry weight \\
\hline \multirow[t]{3}{*}{ Mustard oil cake } & 1 & $11.85^{\mathrm{de}_{(20.13)}}$ & $24.53^{d_{(29.69)}}$ \\
\hline & 2 & $19.62^{b c}(26.26)$ & $28.68^{\mathrm{c} \tilde{o}_{(32.36) ~ B}}$ \\
\hline & 3 & $50.92^{\mathrm{a}}{ }_{(45.52)}$ & $55.82^{\mathrm{a}}{ }_{(48.34)}$ \\
\hline \multirow[t]{3}{*}{ Sesame oil cake } & 1 & $0.00_{(1.65)}^{f}$ & $5.35^{\mathrm{j}_{(13.38)}}$ \\
\hline & 2 & $11.48^{\mathrm{de}_{(19.80)}}$ & $21.65^{\mathrm{e}}(27.73)$ \\
\hline & 3 & $17.22^{c_{(}(24.49)}$ & $35.30^{b}{ }_{(36.45)}$ \\
\hline \multirow[t]{3}{*}{ Soybean oil cake } & 1 & $9.62^{e}{ }_{(18.06)}$ & $12.10^{h_{(20.34)}}$ \\
\hline & 2 & $17.59^{c}{ }_{(24.79)}$ & $18.94^{f}(25.80)$ \\
\hline & 3 & $25.18^{\mathrm{b}}(30.11)$ & $30.48^{c}(33.51)$ \\
\hline \multirow[t]{3}{*}{ Coconut oil cake } & 1 & $0.00_{(1.65)}^{f}$ & $3.85^{k}(11.31)$ \\
\hline & 2 & $8.51^{\mathrm{e}}(16.94)$ & $13.73^{g}(21.74)$ \\
\hline & 3 & $15.18^{\mathrm{cd}}(22.91)$ & $18.87_{(25.75)}^{f}$ \\
\hline \multirow[t]{3}{*}{ Tea waste } & 1 & $0.00_{(1.65)}$ & $0.00_{(1.65)}^{\prime}$ \\
\hline & 2 & $0.00_{(1.65)}^{f}$ & $0.00^{\prime}(1.65)$ \\
\hline & 3 & $0.00_{(1.65)}^{f}$ & $7.31^{i}(15.68)$ \\
\hline Control & & $90.00 \mathrm{~mm}$ & $0.442 \mathrm{~g}$ \\
\hline
\end{tabular}

${ }^{\beta}$ Figures within the parentheses are the transformed (arcsine) values. ${ }^{\circ}$ Means within same column followed by a common letter(s) are not significantly different $(\alpha=0.05)$.

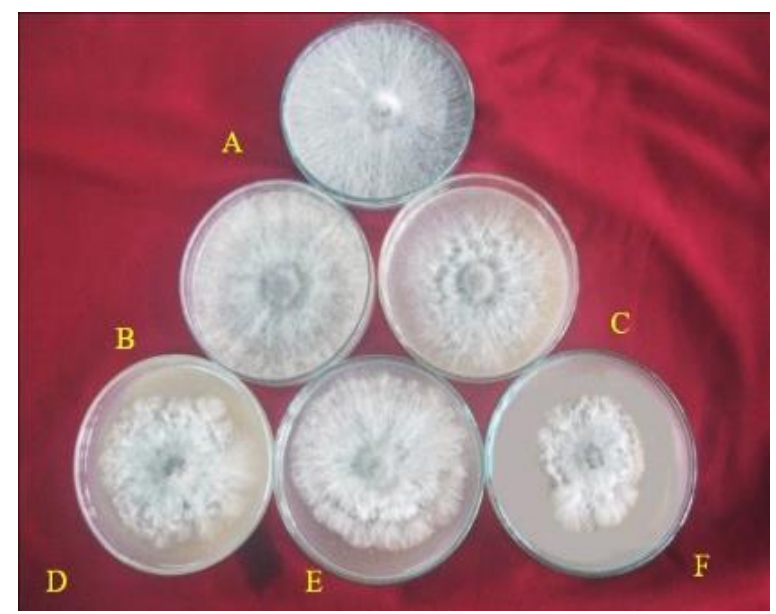

Fig. 5. Effect of organic amendments on radial growth of $M$. phaseolina at $3 \%$ concentration $(A=C o n t r o l, B=T e a$ waste, $C=C$ Coconut oil cake, $\mathrm{D}=$ Soybean oil cake, $\mathrm{E}=$ Sesame oil cake, $\mathrm{F}=$ Mustard oil cake). 
Integrated effect of bio-agent, fungicide, and organic amendment:

Effect on soybean charcoal rot:

The lowest pre-and post-emergence, as well as total seedling mortality, were found in the treatment $\mathrm{T}_{1}(4.38,0.00$, and $4.38 \%)$ where no pathogen was inoculated. But, the highest $80.47 \%$ reduction of seedling mortality was recorded in the treatments $\mathrm{T}_{9}$. On the contrary, significantly the lowest reduction of seedling mortality was observed in the treatment $T_{5}$ but identical with $T_{3}$ (Table 7). Moreover, disease incidence and severity of charcoal rot of soybean were also influenced by the application of bio-agent, fungicide and organic amendment either alone or in combination. The lowest disease incidence $6.50 \%$ and severity $2.08 \%$ was observed in the treatment $\mathrm{T}_{9}$ followed by the treatments $T_{6}$, and $T_{7}$ (Table 8 and Fig. 6).

Table 7. Effect of bio-agent, fungicide, and organic amendment on seedling mortality of soybean

\begin{tabular}{|c|c|c|c|c|}
\hline \multirow[t]{2}{*}{ Treatments $^{\varnothing}$} & \multicolumn{3}{|c|}{ \% Seedling mortality } & \multirow[t]{2}{*}{ \% Reduction } \\
\hline & Pre-emergence & Post-emergence & Total & \\
\hline $\mathrm{T}_{1}$ & $4.38_{(12.08)}$ & $0.00_{(1.65)}$ & $4.38^{f}{ }_{(12.08)}$ & - \\
\hline $\mathrm{T}_{2}$ & $23.68_{(29.12)}$ & $14.47_{(22.36)}$ & $38.15^{\text {a õ }}$ (38.14) B & - \\
\hline$T_{3}$ & $17.54_{(24.76)}$ & $11.84_{(20.12)}$ & $29.38^{\mathrm{bc}}(32.82)$ & 22.98 \\
\hline $\mathrm{T}_{4}$ & $15.35_{(23.06)}$ & $10.52_{(18.93)}$ & $25.87^{\mathrm{cd}}(30.57)$ & 32.18 \\
\hline$T_{5}$ & $20.17_{(26.96)}$ & $14.03_{(22.00)}$ & $34.21^{\mathrm{ab}}{ }_{(35.79)}$ & 10.32 \\
\hline$T_{6}$ & $10.96_{(19.33)}$ & $3.94_{(11.45)}$ & $14.91_{(22.71)}$ & 60.91 \\
\hline $\mathrm{T}_{7}$ & $14.03_{(22.00)}$ & $5.70_{(13.81)}$ & $19.73^{\mathrm{de}}(26.37)$ & 48.28 \\
\hline$T_{8}$ & $15.78_{(23.41)}$ & $7.01_{(15.36)}$ & $22.80^{\mathrm{cd}}(28.52)$ & 40.23 \\
\hline$T_{9}$ & $5.26_{(13.26)}$ & $2.19_{(8.51)}$ & $7.45^{f}(15.84)$ & 80.47 \\
\hline
\end{tabular}

Table 8. Effect of bio-agent, fungicide, and organic amendment on charcoal rot disease of soybean

\begin{tabular}{|c|c|c|c|c|}
\hline \multirow[t]{2}{*}{ Treatments $^{\varnothing}$} & \multirow[t]{2}{*}{$\%$ disease incidence } & \multirow[t]{2}{*}{ PDI } & \multicolumn{2}{|c|}{ \% Disease reduction } \\
\hline & & & Incidence & PDI \\
\hline $\mathrm{T}_{1}$ & $0.00^{i}(1.28)$ & $0.00^{\mathrm{c} \tilde{\boldsymbol{o}}_{(1.28) B}}$ & - & - \\
\hline $\mathrm{T}_{2}$ & $32.73^{a}(34.89)$ & $18.17^{\mathrm{a}}(25.22)$ & - & - \\
\hline$T_{3}$ & $25.20^{c_{(30.13)}}$ & $11.88^{b}{ }_{(20.14)}$ & 23.00 & 34.61 \\
\hline $\mathrm{T}_{4}$ & $22.00^{d_{(27.97)}}$ & $11.52^{b}(19.81)$ & 32.78 & 36.59 \\
\hline$T_{5}$ & $29.35_{(32.80)}^{b}$ & $13.96^{\mathrm{ab}}(21.90)$ & 10.32 & 23.17 \\
\hline $\mathrm{T}_{6}$ & $12.79^{g}(20.95)$ & $9.07^{\mathrm{b}}(17.50)$ & 60.92 & 50.08 \\
\hline $\mathrm{T}_{7}$ & $16.83_{(24.22)}^{f}$ & $9.76^{b}{ }_{(18.18)}$ & 48.57 & 46.28 \\
\hline $\mathrm{T}_{8}$ & $19.56^{\mathrm{e}}{ }_{(26.24)}$ & $11.17^{\mathrm{b}}{ }_{(19.50)}$ & 40.23 & 38.52 \\
\hline$T_{9}$ & $6.50^{h}{ }_{(14.77)}$ & $2.08^{c}(5.68)$ & 80.14 & 88.55 \\
\hline
\end{tabular}

${ }^{\beta}$ Figures within the parentheses are the transformed (arcsine) values. ${ }^{\circ}$ Means within same column followed by a common letter(s) are not significantly different $(\alpha=0.05)$.

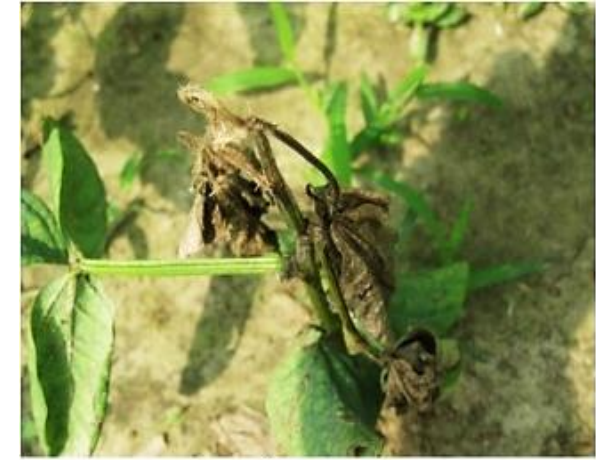

A

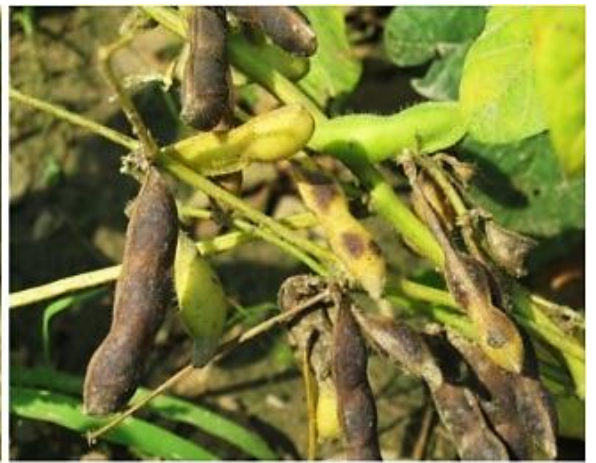

B

Fig. 6. Symptoms of charcoal rot disease at soybean field $(A-B$, Where $A=$ Seedling stage $B=$ Mature stage).

Effect on yield and yield components of soybean:

The highest plant height, number of pods per plant and seed weight were observed in the treatment $T_{9}$ followed by $T_{1}$, and $T_{6}$. Growth promotion in the treatment $\mathrm{T}_{3}$ appeared significantly the most inferior in comparison to the other treatments and identical to the control-2 treatment. In the case of disease reduction, the treatment $T_{5}$ was significantly inferior to the treatment $T_{3}$ but significantly higher in improving the growth promotion parameter. Different treatments also showed significant variation in total yield over control-2. The highest ( $2.31 \mathrm{t} / \mathrm{ha}$ ) seed yield was obtained from the treatment $T_{9}$, where colonized $T$. harzianum, Provax $200 W P$ treated seed and mustard oil cake were used. Considerably higher and statistically similar seed yield over control-2 was obtained in the treatment $T_{1}, T_{6}, T_{7}$, and $T_{8}$, respectively. On the other hand, the lowest yield (1.13 t/ha) was obtained in the treatment $\mathrm{T}_{2}$ where fresh seeds were sown in M. phaseolina isolate MSP-4 inoculated soil without application of any means of control (Table 9). 
Table 9. Effect of bio-agent, fungicide, and organic amendment on soybean yield production

\begin{tabular}{|c|c|c|c|c|}
\hline Treatments $\varnothing$ & Plant height (cm) & No. of pod/ plant & Yield (t/ha) & $\%$ Increased \\
\hline $\mathrm{T}_{1}$ & $74.77^{\mathrm{cd}}$ & 50.44 ef & $2.06^{a b} \mathrm{o}$ & - \\
\hline $\mathrm{T}_{2}$ & $69.37^{\mathrm{e}}$ & $45.78^{g}$ & $1.13^{f}$ & - \\
\hline $\mathrm{T}_{3}$ & $73.53^{d}$ & $49.22^{f}$ & $1.47^{\mathrm{e}}$ & 30.09 \\
\hline $\mathrm{T}_{4}$ & $74.60^{\mathrm{cd}}$ & 51.78 de & 1.70 cde & 50.44 \\
\hline$T_{5}$ & $77.27^{b c}$ & $54.00^{b c}$ & 1.54 de & 36.28 \\
\hline $\mathrm{T}_{6}$ & 76.57 bc & $52.56^{\mathrm{cd}}$ & $1.86^{b c}$ & 64.60 \\
\hline $\mathrm{T}_{7}$ & $78.57 \mathrm{ab}$ & $55.11^{b}$ & $1.81 \mathrm{bcd}$ & 60.18 \\
\hline $\mathrm{T}_{8}$ & $78.20^{a b}$ & $54.22^{b c}$ & 1.74 cde & 53.98 \\
\hline $\mathrm{T}_{9}$ & $80.67^{a}$ & $58.67^{a}$ & $2.31^{a}$ & 104.42 \\
\hline
\end{tabular}

õ Means within same column followed by a common letter(s) are not significantly different $(\alpha=0.05)$.

${ }^{\varnothing} T_{1}=$ Fresh seeds sown in sterilized ( $5 \%$ formaldehyde) soil (Control-1), $T_{2}=$ Soil inoculated with pathogen (SIP) + Fresh seeds (Control-2), $T_{3}=$ SIP + Fungicide Treated Seeds (FTS), $T_{4}=$ SIP + Wheat Grains Colonized T. harzianum isolate ISR-26 (WGCT) + Fresh seeds, $T_{5}=$ SIP + Organic Amendment $(\mathrm{OA})+$ Fresh seeds, $\mathrm{T}_{6}=\mathrm{SIP}+\mathrm{WGCT}+\mathrm{FTS}, \mathrm{T}_{7}=\mathrm{SIP}+\mathrm{WGCT}+\mathrm{OA}+$ Fresh seeds, $\mathrm{T}_{8}=\mathrm{SIP}+\mathrm{OA}+\mathrm{FTS}, \mathrm{and} \mathrm{T}_{9}=\mathrm{SIP}+\mathrm{WGCT}+\mathrm{OA}+\mathrm{FTS}$.

\section{DISCUSSION}

In Bangladesh, this is the first comprehensive study that aimed to develop a sustainable integrated management package against the charcoal rot disease of soybean and surge the yield production at open field condition. Before going to the field trial, a series of preliminary experiments were conducted to select a virulent isolate of $M$. phaseolina, an effective antagonistic isolate of Trichoderma sp., suitable fungicide and organic amendment. Exactly seven isolates of $M$. phaseolina were isolated from naturally infected crops and characterized based the morphological features such as pycnidia, pyncidiospores, conidiophores, etc. (Wheeler, 1975). In addition, the pathogenicity test was performed in pot culture with the isolates of $M$. phaseolina. Among the 7 isolate of $M$. phaseolina, isolate MPS-4 was found highly virulent and caused $74.06 \%$ total soybean seedling mortality. The results of the pathogenicity test are completely agreed with Hashem (2004) who observed the ability of $M$. phaseolina to infect soybean roots and produced the symptoms of damping-off and root-rot diseases. On the contrary, 87 isolates of $T$. harzianum were screened against $M$. phaseolina isolate MPS-4. Among the 87 isolates, $T$. harzianum isolate ISR-26 showed the highest inhibition of radial growth (81.85\%) of test pathogen. The study of the screening of $T$. harzianum isolates against the major soil borne pathogens such as Fusarium oxysporum f. sp. lentis, Rhizoctonia solani and Sclerotium rolfsii by dual culture technique were reported by other investigators (Das et al., 2019; Rubayet et al., 2020). Another trial was implemented on five fungicides namely, Cabrio*Top, Conza 5\%EC, Bavistin 50WP, Dithane M-45, and Provax 200WP at three different concentrations viz., 75, 150, and 300 ppm in-vitro against M. phaseolina isolate MPS-4 for selecting the most effective fungicide with appropriate concentration. The results of the present study revealed that Conza 5\%EC was the most effective fungicide against $M$. phaseolina isolate MSP-4 which was followed by Provax $200 \mathrm{WP}$, and Bavistin 50WP, respectively. Further, Provax 200WP was selected for minimizing the inoculum density of test pathogen at field level. Actually, Provax 200WP is a popular seed treating fungicide which has a great sustainable potentiality to control the soil as well as seed borne pathogens. Seed treating fungicide could play a preventive measure strikingly rather than foliar spray. However, the present experiment is supported by Pant and Mukhopadhayay (2001). They observed that Provax 200WP (Vitavax) had highly inhibitory against the R. solani, S. rolfsii and $M$. phaseolina, and no inhibitory effect on biocontrol agents such as $T$. harzianum. The last preliminary laboratory evaluation was the determination of effective organic amendment against the test pathogen. Among the five-organic amendment, mustard oil cake was found to be most effective and significantly superior to all other organic amendments in inhibiting the growth of $M$. phaseolina. Sesame oil cake and soybean oil cake also had a considerable effect in reducing the growth of selected pathogen but tea waste and coconut oilcake was found less effective against pathogen. This result of the present investigation revealed that mustard oilcake was the most effective in inhibiting the growth of M. phaseolina and had a significant impact on yield production of soybean. Sudha and Prabhu (2008) found that, farmyard manure @ $12.5 \mathrm{t} / \mathrm{ha}$ and neem cake @ $250 \mathrm{~kg} / \mathrm{ha}$ was declined the inoculum levels of $M$. phaseolina and significantly reduced the incidence of charcoal rot of sunflower to 13.30 and $15.00 \%$, respectively from $63.30 \%$ in the control.

Finally, an integrated management trial was conducted against the M. phaseolina isolate MPS-4 inoculated soil condition. The integrated management trial was composed of wheat grain colonized $T$. harzianum isolate ISR-26, mustard oil cake and seed treatment with Provax 200WP fungicide. Integration of Trichoderma with Provax 200WP and mustard oil cake under treatment $T_{9}$ was appeared to be the best and significantly superior in comparison to other treatments in reducing the seedling mortality, disease incidence and disease severity and increasing the yield of soybean. Rubayet and Bhuiyan (2016) reported that, fungicide, organic amendment and T. harzianum either individual or in combination of wheat grain colonized T. harzianum @ 90 g/ $\mathrm{m}^{2}$ with Provax 200WP @ 0.02\% treated seed and mustard oilcake @ $60 \mathrm{~g} / \mathrm{m}^{2}$ was significantly decreased the pre- and post-emergence mortality of potato seedling caused by $S$. rolfsii and also significantly increased the yield of potato tuber. On the other hand, bio-agent ( $T$. harzianum, isolate T-2), fungicide (Iprodione, Rovral 50WP) and plant leaf extract (Azadirachta indica) was reduced strikingly the Alternaria blight diseases of radish caused by Alternaria brassicae AB-2 isolate (Arefin et al., 2019). Results of the present study indicated that the application of different treatments in the field; seed yield and yield contributing components were significantly increased by all the treatments over treatment $T_{2}$. Statistically, the highest yield was found with the treatment $T_{9}$. The yield increased not only because of declining plant disease but also might be due to the secretion of different growthpromoting substances in the soil by bio-agent T. harzianum. According to Altomare et al. (1999) reported that Trichoderma produced various chemical substances which are accelerated to solubilize minerals, for instance, rock phosphate, $\mathrm{Zn} \mathrm{Mn}^{4+}, \mathrm{Fe}^{3+}, \mathrm{Cu}^{2+}$ etc. and increased iron availability. These nutrient substances might be subsidized in increasing crop yield. Besides, seed treatment was found more effective than foliar spray in case of individual or integrated application of chitosan and $T$. harzianum spore suspension for the protection of southern blight disease and also increases the yield of carrot (Ahmed et al., 2019). Moreover, T. harzianum based treatment at different formulation was appeared to be an excellent bio-agent in controlling anthracnose disease of chilli caused by $C$. capsici as well as significantly increased of growth and yield (Simi et al., 2019).

\section{CONCLUSION}

The result of the present study revealed that integrated use of bio-agent ( $T$. harzianum isolate ISR-26), seed treating fungicide (Provax 200WP), and organic amendment (Mustard oil cake) delivered the effective control measure against charcoal rot disease of soybean caused by $M$. phaseolina isolate MSP-4. Moreover, this technique may be a sustainable alternative to reduce the pathogen population density as well as increasing soybean production at field soil. 
Acknowledgements: The authors express their gratefulness to the Ministry of Science and Technology, Dhaka, Bangladesh for providing financial support to accomplish this research work.

Funding: Ministry of Science and Technology, Dhaka, Bangladesh.

Conflict of Interest: The authors declare no conflict of interest.

\section{REFERENCES}

Abd-Elsalam, K. A. (2010). Genetical and biological control of cotton ashy stem caused by Macrophomina phaseolina in outdoor pot experiment. Saudi Journal of Biological Sciences, 17(2), 147-152.

Abd-El-Khair, Khalifa, H., Karima, R. K. M. \& Haggag, H. E. (2010). Effect of Trichoderma species on damping off diseases incidence, some plant enzymes activity and nutritional status of bean plants. Journal of American Science, 6(9): 486-497.

Ahmed, M. U., Bhuiyan, M. K. A., Hossain, M. M., Rubayet, M. T. \& Khaliq, Q. A. (2019). Efficacy of chitosan and bio-agent in controlling southern blight disease of carrot caused by Sclerotium rolfsii and improvement the crop production. Research in Agriculture and Veterinary Science, 3(3): 113-125.

Altomare, C., Norvell, W. A., Bjorkman, T. \& Harman, G. C. (1999). Solubilization of phosphates and micronutrients by the plant- growth promoting and biocontrol fungus Trichoderma harzianum Rifai 1295-22. Applied and Environmental Microbiology, 65(7): 2926-2933.

Aly, A. A., Abdel-Sattar, M. A., Omar, M. R. \& Abd-Elsalam, K. A. (2007). Differential antagonism of Trichoderma sp. against Macrophomina phaseolina. Journal of Plant Protection Research, 47(2): 91-102.

Anonymous. 2018. Statistical Year Book of Bangladesh. Bangladesh Statistics Division, Ministry of Planning, Govt. of the People's Republic of Bangladesh, $59 \mathrm{P}$.

Arefin, M. N., Bhuiyan, M. K. A. \& Rubayet, M. T. (2019). Integrated use of fungicide, plant extract and bio-agent for management of Alternaria blight disease of Radish (Raphanus sativus L.) and quality seed production. Research in Agriculture and Veterinary Science, 3(1): 10-21.

Barnett, H. L. \& Hunter, B. B. (1972). Illustrated genera of Imperfect fungi. Burges's Publishing Company,. Minneapolis, 241 P.

Das, I. R., Bhuiyan, M. K. A., Jannat, R., Kayesh, E., Rubayet, M. T. \& Arefin, M. N. (2019). Effect of bio-fortified compost in controlling soilborne diseases of lentil (Lens culinaris L.) and enhance the crop growth and yield. Advances in Biology \& Earth Sciences, 4(2): 93-106.

Dhingra, O. D. \& Sinclair, J. B. (1985). Basic Plant Pathology Methods. CRC Press, Inc. Boca Raton, Florida. Pp. $132-163$.

Hashem, M. (2004). Biological control of two phytopathogenic fungal species isolated from the rhizoplane of soybean (Glycine max). Czech Mycology, 56(3-4): 223-238.

Liton, M. J. A., Bhuiyan, M. K. A., Jannat, R., Ahmed, J. U., Rahman, M. T. \& Rubayet, M. T. (2019). Efficacy of Trichoderma-fortified compost in controlling soil-borne diseases of bush bean (Phaseolus vulgaris L.) and sustainable crop production. Advances in Agricultural Science, $7(2):$ 123-136.

Mian, I. H. (1995). Methods in plant pathology. IPSA-JICA project publication no 24. Institute of Post Graduate Studies in Agriculture. Gazipur1706, Bangladesh.

Pant, R. \& Mukhopadhyay, A. N. (2001). Integrated management of seed and seedling rot complex of soybean. Indian Phytopathology, 54(3): 346-350.

Rahman, M. M., Ali, M. A., Ahmad, M. U. \& Dey, T. K. (2013). Effect of tuber-borne inoculum of Rhizoctonia solani on the development of stem canker and black scurf of potato. Bangladesh Journal of Plant Pathology, 29(1\&2): 29-32.

Rahman, M. T., Bhuiyan, M. K. A., Karim, M. A. \& Rubayet, M. T. (2018). Screening of soybean resistance genotypes against Fusarium oxysporum, Macrophomina phaseolina, Rhizoctonia solani and Sclerotium rolfsii. Research in Agriculture and Veterinary Science, 2(3): 139-156.

Rahman, M. T., Rubayet, M. T., Khan, A. A. \& Bhuiyan, M. K. A. (2020a). Integrated management of fusarium root rot and wilt disease of soybean caused by Fusarium oxysporum. International Journal of Biosciences, 17(2): 83-96.

Rahman, M. T., Rubayet, M. T. \& Bhuiyan, M. K. A. (2020b). Integrated management of rhizoctonia root rot disease of soybean caused by Rhizoctonia solani. Nippon Journal of Environmental Science, 1(7), 1018.

Razaq, M., Rab, A., Alam, H., Salahuddin, Saud, S. \& Ahmad, Z. (2015). Effect of potash levels and plant density on potato yield. Journal of Biology, Agriculture and Healthcare, 5(13): 54-62.

Rubayet, M. T. \& Bhuiyan, M. K. A. (2016). Integrated management of stem rot of potato caused by Sclerotium rolfsii. Bangladesh Journal of Plant Pathology, 32(1\&2): 7-14.

Rubayet, M. T., Bhuiyan, M. K. A. \& Akanda, M. A. M. (2011). Effect of fungicides, organic amendments and antagonist on in vitro growth of Sclerotium rolfsii. Bangladesh Journal of Plant Pathology, $27(1$ \&2): 47-52.

Rubayet, M. T., Bhuiyan, M. K. A. \& Hossain, M. M. (2017). Effect of soil solarization and biofumigation on stem rot disease of potato caused by Sclerotium rolfsii. Annals of Bangladesh Agriculture, 21(1\&2): 49-59.

Rubayet, M. T., Bhuiyan, M. K. A., Jannat, R., Masum, M. M. I. \& Hossain, M. M. (2018). Effect of biofumigation and soil solarization on stem canker and black scurf diseases of potato (Solanum tuberosum L.) caused by Rhizoctonia solani isolate PR2. Advances in Agricultural Science, 6(3): 33-48.

Rubayet, M. T., Prodhan, F., Hossain, M. S., Ahmed, M., Mamun, M. A. A. \& Bhuiyan, M. K. A. (2020). Use of non-chemical methods for the management of southern blight disease of carrot incited by Sclerotium rolfsii. Journal of Agriculture and Applied Biology, 1(2): $74-85$.

Rubayet, T. \& Bhuiyan, M. K. A. (2012). Compatibility of an Isolate of Trichoderma harzianum with fungicides and organic amendments. Bangladesh Journal of Plant Pathology, 28(1 \&2): 63-66.

Simi, S. A., Jannat, R., Rubayet, M. T. \& Bhuiyan, M. K. A. (2019). Efficacy of bio-fortified compost in controlling anthracnose disease of chilli caused by Colletotrichum capsici and improvement the crop production. Scholars Academic Journal of Bioscience, 7(12): $482-489$.

Sinclair, J. B. (1988). Anthracnose of soybean. In: Soybean Diseases of North Central Region. American Phytopathological Society, St. Paul, Minnesota, USA, 104 P.

Sudha, A. \& Prabhu, S. (2008). Evaluation of organic soil amendments against Macrophomina Phaseolina (Tassi). Journal of Biopesticides, 1(2): $143-145$.

Sundar, A. R., Das, N. D. \& Krishnaveni, D. (1995). In vitro antagonism of Trichoderma spp. against two fungal pathogens of castor. Indian Journal of Plant Protection, 23(2): 152-155.

Wheeler, H. (1975). Plant pathogenesis. Academic, Press, New York and London, Pp. 2-3.

Yesil, S. \& Bastas, K. K. (2016). Genetic Variability of Macrophomina phaseolina isolates from dry beans in Turkey. Turkish Journal of Agriculture - Food Science and Technology, 4(4): 305-312.

Yuen, G. Y., Craig, M. I. \& Geisler, L. J. (1994). Biological control of Rhizoctonia solani on tall fescue using fungal antagonists. Plant Disease, 78: 118-123. 


\section{المكافحة المتكاملة لمرض العفن الفحمى لفول الصويا الناجم عن ماكروفومينا فاصولينا}

تحميدور الرحمن، محمد تنبير رباعيت * ، أبو أشرف خان، محمد خورشيد علم بويان

قسم أمراض النبات ، كلية الزراعة ، بانغاباندو ، جامعة الشيخ مجبور الرحمن الزراعية ، غازيبور -1706 ، بنغلاديش tanbir86plp@gmail.com:برجئ

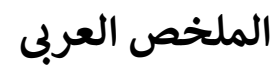

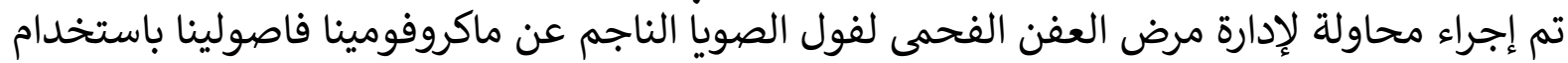

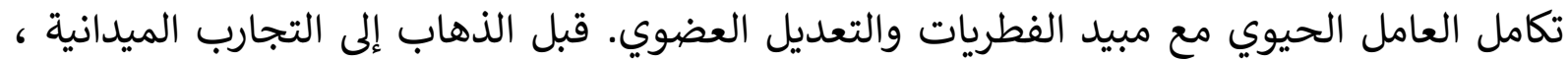

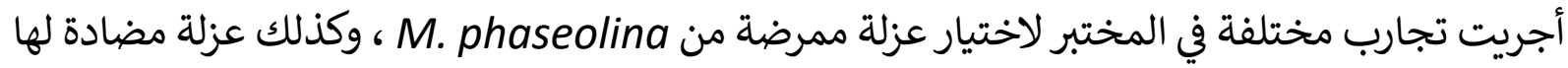

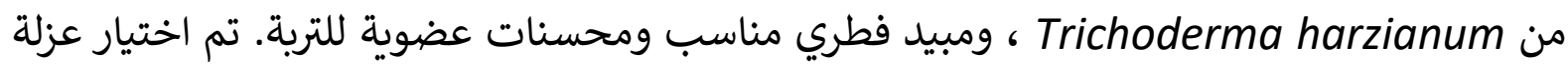

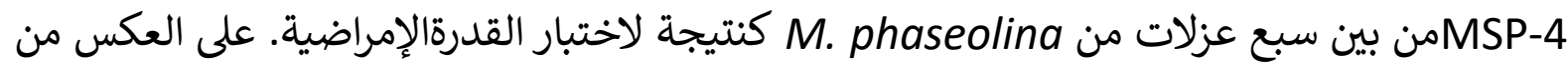

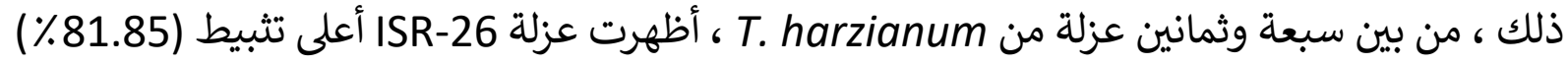

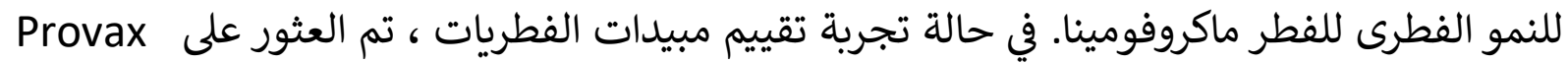
200WP

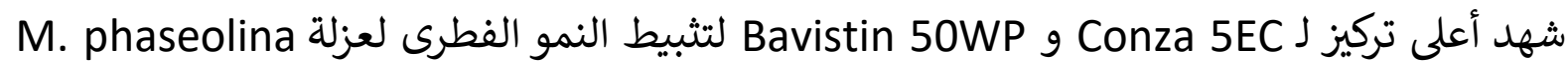

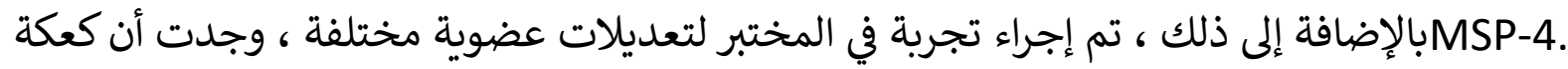

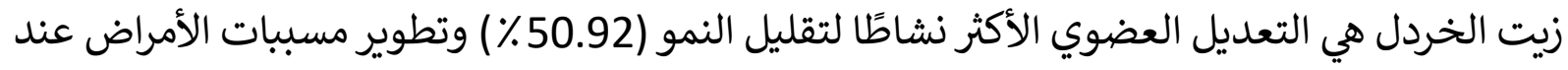

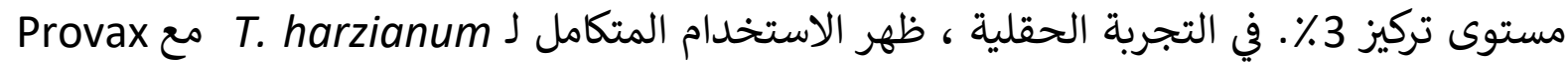

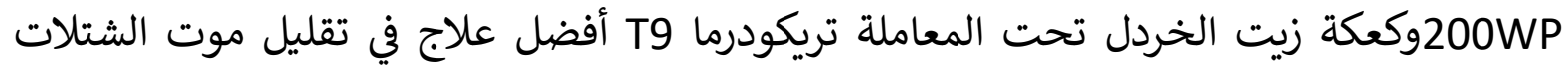

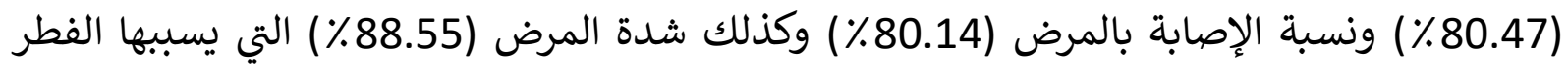

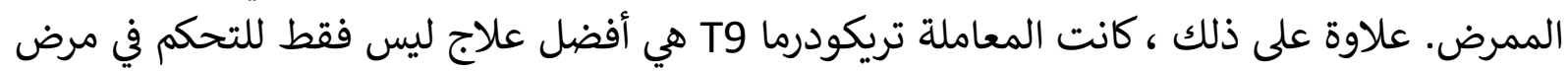

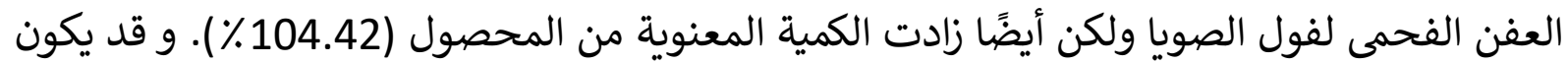

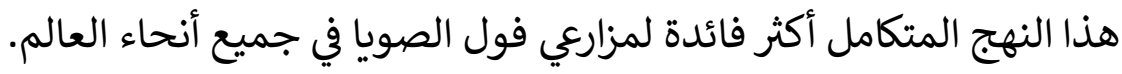

الكلمات المفتاحية: ماكروفومينا فاصولينا، تريكودرما هارزينم، مبيدات الفطريات، محسنات عضوية، وفول الصويا 